\title{
Pengaruh Penambahan Air Perasan Daun Pepaya (Carrica Papaya L) Dalam Air Minum Terhadap Performans Ayam Broiler
}

\author{
The Effect of the Addition of Papaya Leaf Juice (Carica Papaya L) in Drinking Water on \\ the Performance of Broiler Chickens
}

\author{
Andy Triwibowo ${ }^{1}$, Novi Eka Wati ${ }^{2}$, dan Miki Suhadi ${ }^{3}$ \\ ${ }^{1}$ Program Studi Peternakan, Fakultas Peternakan, Universitas Tulang Bawang Lampung \\ Jl. Gajah Mada. No. 34 Kota Baru, Bandar Lampung 35121 \\ Corresponding e-mail: andytriwibowoo@gmail.com
}

\begin{abstract}
Herbal plants can be used as feed additive, on of which is the papaya plant (Carrica papaya L). The reseach was conducted on 11-27 September 2020 at street Wolter Monginsidi alley Nuri number 55, Teluk Betung North District, Bandar Lampung. This study aims to determine the effect of adding papaya leaf juice in drinking water to the performance broiler chickens. The material used was 96 broiler chickens ranging from 5-21 days of age. The method used was a Completely Randomized Design (CRD) with 4 treatments and 4 replications. The treatments given was control drinking water without additional $(\mathrm{P} 0)$, control drinking water $+5 \mathrm{ml}$ papaya leaf juice/liter of water $(\mathrm{P} 1)$, control drinking water $+10 \mathrm{ml}$ papaya leaf juice/liter of water (P2), control drinking water $+15 \mathrm{ml}$ papaya leaf juice/liter of water (P3). The result showed that the addition of papaya leaf juice up to level 1,5\% did not have a significant effect on the performance of broiler chickens at weeks 1,2, and 3. Based on the reseach result it can be concluded that the addition of papaya leaf juce in drinking water up to level $1.5 \%$ has not had a significant effect $(\mathrm{P}>0,05)$ on performance broiler chicken.
\end{abstract}

Keywords : Broiler Chicken, Papaya Leaf Juice, Drinking Water, Broiler Performance

\begin{abstract}
ABSTRAK
Tanaman herbal dapat digunakan sebagai feed additive salah satunya adalah tanaman papaya (Carrica papaya L). Penelitian ini dilaksanakan pada tanggal 11-27 September 2020 di Jl. Wolter Monginsidi gang Nuri No 55, Kecamatan Teluk Betung Utara, Bandar Lampung. Penelitian ini bertujuan untuk mengetahui pengaruh penambahan air perasan daun pepaya dalam air minum terhadap performans ayam broiler. Materi yang digunakan adalah 96 ekor ayam broiler mulai dari umur 5-21 hari. Metode yang digunakan adalah dengan percobaan Rancangan Acak Lengkap (RAL) dengan 4 perlakuan dan 4 ulangan. Perlakuan yang diberikan yaitu air minum kontrol tanpa tambahan (P0), air minum kontrol $+5 \mathrm{ml}$ air perasan daun pepaya per liter air (P1), air minum kontrol $+10 \mathrm{ml}$ air perasan daun pepaya per liter air (P2), air minum kontrol $+15 \mathrm{ml}$ air perasan daun pepaya per liter air (P3). Hasil penelitian menunjukan bahwa penambahan air perasan daun pepaya sampai dengan level $1,5 \%$ tidak memberikan pengaruh nyata terhadap performans ayam broiler pada minggu 1, 2, dan 3. Berdasarkan hasil penelitian dapat disimpulkan bahwa penambahan air perasan daun pepaya dalam air minum sampai dengan level 1,5\% belum memberikan pengaruh nyata $(\mathrm{P}>0,05)$ terhadap performans ayam broiler.
\end{abstract}

Kata Kunci: Ayam Broiler, Air Perasan Daun Pepaya, Air Minum, Performans Ayam Broiler

\section{PENDAHULUAN}

Daging ayam broiler merupakan sumber protein hewani yang banyak dikonsumsi oleh manusia, karena harga daging ayam broiler lebih murah dibandingkan harga daging lainnya. Berdasarkan data Dirjen Peternakan dan Kesehatan Hewan (2018) jumlah konsumsi daging ayam 
broiler adalah $5.579 \mathrm{~kg} / \mathrm{kapita} / \mathrm{tahun}$, nilai tersebut lebih tinggi daripada daging ayam kampung sebanyak $0.730 \mathrm{~kg} / \mathrm{kapita} / \mathrm{tahun}$, daging kerbau sebanyak $0.469 \mathrm{~kg} / \mathrm{kapita} / \mathrm{tahun}$ maupun daging lainnya sebanyak $0.052 \mathrm{~kg} / \mathrm{kapita} / \mathrm{tahun}$. Produksi ayam broiler di pengaruhi oleh beberapa faktor yaitu genetik dan lingkungan.. Faktor lingkungan yang di maksud antara lain : pakan, air minum, suhu lingkungan, dan lain sebagainya (Nofyangtri, 2007). Feed additive merupakan bahan pakan tambahan yang diberikan kepada ternak melalui pakan maupun air minum.

Feed additive terdiri dari 2 jenis yaitu feed additive alami dan feed additive buatan (sintetis). Tanaman herbal merupakan feed additive alami yang mudah ditemukan, salah satu tanaman herbal yang dapat digunakan adalah tanaman papaya (Carrica papaya L).

Daun pepaya merupakan tanaman obat-obatan yang mengandung senyawa alkaloida, enzim proteolitik, papain, khimopapain, dan lisozim yang berguna pada proses pencernaan dan mempermudah kerja usus (Kamaruddin dan Salim, 2003). Hasil Analisis Laboratorium Nutrisi Ternak Ruminansia dan Kimia Makanan Ternak Fakultas Peternakan Universitas Padjajaran (2007) menambahkan bahwa daun papaya mengandung protein kasar sebesar 20,88 \%, kalsium 0,99 \%, fosphor 0,47 \%, dan gross energy $2912 \mathrm{kkal} / \mathrm{kg}$. Penambahan air perasan daun pepaya pada air minum diharapkan mampu meningkatkan konsumsi pakan dan air minum sehingga dapat menngkatkan pertambahan bobot badan. Kurangnya informasi mengenai pertambahan air perasan daun pepaya sebagai feed additive alami pada ayam broiler mendorong adanya penelitian mengenai pertambahan air perasan daun pepaya pada air minum terhadap peformans ayam broiler.

\section{METODOLOGI}

\section{Materi Penelitian}

Jenis penelitian ini adalah jenis penelitian eksperimental, yaitu penelitian digunakan untuk mencari pengaruh perlakuan tertentu terhadap performans ayam broiler. Lokasi Penelitian dilakukan di kandang ayam milik Bapak Endang Sukmawan, yang berada di Jl. Wolter Monginsidi gang Nuri No 55, Kelurahan Pengajaran, Kecamatan Teluk Betung Utara, Bandar Lampung. Penelitian dilaksanakan pada tanggal 11-27 September 2020 dengan masa pemeliharaan 21 hari dan diberi perlakuan 17 hari menggunakan ayam boiler dengan penambahan air perasan daun pepaya pada air minum.

Alat yang digunakan dalam penelitian ini adalah kandang, timbangan, wadah pakan, wadah minum, lembar pengamatan, handphone, dan alat tulis. Bahan yang digunakan dalam penelitian ini yaitu 96 ekor ayam broiler mulai dari 5 hari - 21 hari yang diberi perlakuan selama 17 hari dengan masa pemeliharaan 21 hari. Ayam ditempatkan dalam 4 petak kandang sesuai dengan jumlah perlakuan. Setiap petak kandang perlakuan dibagi menjadi 4 bagian sebagai ulangan. Setiap ulangan terdapat 6 ekor ayam broiler.

Perlakuan yang diberikan adalah : 
$\mathrm{P} 0=$ air minum kontrol tanpa tambahan

$\mathrm{P} 1=$ air minum kontrol $+5 \mathrm{ml}$ air perasan daun pepaya per liter air

$\mathrm{P} 2=$ air minum kontrol $+10 \mathrm{ml}$ air perasan daun pepaya per liter air

P3 = air minum kontrol $+15 \mathrm{ml}$ air perasan daun pepaya per liter air

Pakan kontrol yang digunakan adalah pakan jadi merk BR 1 CP 511-B yang diproduksi oleh PT. Charoen Pokphand Indonesia. Kandungan nutrisi pakan kontrol tersaji pada tabel 4.

Tabel 4. Kandungan Nutrisi Pakan merk CP 511-B

\begin{tabular}{ccc}
\hline Nutrsi & Max-Min & Jumlah \\
\hline Kadar Air & Max & $13.0 \%$ \\
Protein & & $22.0-23.0 \%$ \\
Lemak & Min & $5.0 \%$ \\
Serat & Max & $5.0 \%$ \\
Abu & Max & $7.0 \%$ \\
Kalsium & Min & $0.9 \%$ \\
Phosor & Min & $0.6 \%$ \\
M.E & & $3020-3120 \mathrm{Kcal} / \mathrm{kg}$
\end{tabular}

Sumber : PT. Charoen Pokphand Indonesia (2020)

\section{Metode Penelitian}

Ayam broiler diberi perlakuan mulai dari umur 5 hari -21 hari dengan perlakuan $\mathrm{P} 0=$ tanpa penambahan air perasan daun pepaya, $\mathrm{P} 1=$ air minum kontrol $+5 \mathrm{ml}$ air perasan daun pepaya per liter air, P2 = air minum kontrol + $10 \mathrm{ml}$ air perasan daun pepaya per liter air, P3 = air minum kontrol $+15 \mathrm{ml}$ air perasan daun pepaya per liter air. Pemberian air minum dilakukan 2 kali yaitu pagi jam 07.00 WIB dan sore hari jam 15.00 WIB. Penimbangan bobot badan dilakukan pada awal dan akhir penelitian.

\section{HASIL DAN PEMBAHASAN}

\section{Pengaruh Perlakuan Terhadap Konsumsi Pakan}

Hasil penelitian menunjukkan bahwa penambahan air perasan daun pepay ( Carrica papaya $L)$ pada air minum ayam broiler tidak berpengaruh nyata $(\mathrm{P}>0,05)$ terhadap konsumsi pakan ayam minggu 1, 2, dan 3. Besarnya konsumsi pakan ayam broiler yang mendapat perlakuan P0, P1, P2 dan P3 tersaji pada 5, 6, dan 7. 
Tabel 5. Konsumsi pakan ayam broiler dengan penambahan air perasan daun pepaya pada minggu 1.

\begin{tabular}{ccc}
\hline \hline Perlakuan & $\begin{array}{c}\text { Rataan } \\
\text { gram/ekor/hari }\end{array}$ & Standar Deviasi \\
\hline P0 & 31,79 & 1,74 \\
P1 & 33,64 & 0,53 \\
P2 & 33,39 & 0,45 \\
P3 & 32,75 & 0,74 \\
\hline
\end{tabular}

Tabel 6. Konsumsi pakan ayam broiler dengan penambahan air perasan daun pepaya pada minggu 2.

\begin{tabular}{ccc}
\hline Perlakuan & $\begin{array}{c}\text { Rataan } \\
\text { gram/ekor/hari }\end{array}$ & Standar Deviasi \\
\hline P0 & 54,16 & 2,39 \\
P1 & 53,57 & 2,79 \\
P2 & 56,60 & 0,78 \\
P3 & 55,51 & 2,09 \\
\hline
\end{tabular}

Tabel 7. Konsumsi pakan ayam broiler dengan penambahan air perasan daun pepaya pada minggu 3.

\begin{tabular}{ccc}
\hline \hline Perlakuan & $\begin{array}{c}\text { Rataan } \\
\text { gram/ekor/hari }\end{array}$ & Standar Deviasi \\
\hline P0 & 97,13 & 1,02 \\
P1 & 95,73 & 4,68 \\
P2 & 99,91 & 1,03 \\
P3 & 94,90 & 5,52 \\
\hline
\end{tabular}

Hasil ini menunjukkan bahwa penambahan air perasan daun pepaya sampai dengan dosis $15 \mathrm{ml} /$ liter tidak berpengaruh terhadap konsumsi pakan ayam pada minggu1, 2, dan 3 . Hal ini di pengaruhi oleh jenis pakan dan kandungan nutrisi pakan yang sama sehingga konsumsi pakan juga sama. Sesuai dengan pendapat Wahju (2004) bahwa faktor yang mempengaruhi konsumsi pakan antara lain umur, nutrisi ransum, kesehatan, bobot badan, suhu, dan kelembapan serta kecepatan pertumbuhan ternak. Faktor lain yang mempengaruhi adalah tingginya suhu dalam kandang (siang hari $30,5^{\circ} \mathrm{C}$ ) dan (malam $28,2^{\circ} \mathrm{C}$ ). Wijayanti et al (2011) berpendapat bahwa konsumsi pakan ayam pedaging pada suhu $28^{\circ} \mathrm{C}$ lebih tinggi daripada suhu $32^{\circ} \mathrm{C}$ akibat cekaman panas.

\section{Pengaruh Perlakuan Terhadap Konsumsi Air Minum}

Hasil penelitian menunjukkan bahwa penambahan air perasan daun pepaya ( Carrica papaya $L)$ pada air minum ayam broiler tidak berpengaruh nyata $(\mathrm{P}>0,05)$ terhadap konsumsi air minum pada minggu 1, 2, dan 3. Besarnya konsumsi air minum ayam broiler yang mendapat perlakuan P0, P1, P2 dan P3 tersaji pada tabel 8, 9, dan 10. 
Tabel 8. Konsumsi air minum ayam broiler dengan penambahan air perasan daun pepaya pada minggu 1.

\begin{tabular}{ccc}
\hline Perlakuan & Rataan ml/ekor/hari & Standar Deviasi \\
\hline P0 & 66,69 & 6,03 \\
P1 & 72,83 & 1,19 \\
P2 & 73,79 & 2,47 \\
P3 & 71,44 & 4,68 \\
\hline
\end{tabular}

Tabel 9. Konsumsi air minum ayam broiler dengan penambahan air perasan daun pepaya pada minggu 2.

\begin{tabular}{ccc}
\hline \hline Perlakuan & Rataan ml/ekor/hari & Standar Deviasi \\
\hline P0 & 113,34 & 8,62 \\
P1 & 109,99 & 4,51 \\
P2 & 117,76 & 10,06 \\
P3 & 112,29 & 8,29 \\
\hline
\end{tabular}

Tabel 10. Konsumsi air minum ayam broiler dengan penambahan air perasan daun pepaya pada minggu 3.

\begin{tabular}{ccc}
\hline \hline Perlakuan & $\begin{array}{c}\text { Rataan } \\
\text { ml/ekor/hari }\end{array}$ & Standar Deviasi \\
\hline P0 & 202,21 & 10,84 \\
P1 & 198,91 & 12,78 \\
P2 & 209,96 & 3,85 \\
P3 & 198,29 & 13,04 \\
\hline
\end{tabular}

Hasil ini menunjukkan bahwa penambahan air perasan daun pepaya sampai dengan dosis $15 \mathrm{ml} /$ liter tidak berpengaruh terhadap konsumsi air minum ayam pada minggu1, 2, dan 3 . Hal ini di sebabkan karena enzim papain yang ada di daun pepaya belum memberikan pengaruh nyata terhadap konsumsi air minum meskipun rasanya yang sedikit pahit. Sesuai dengan pendapat Wahju (2004) bahwa rasa (taste) pada ayam memegang peranan yang relatif kecil untuk menentukan pakan dan air minum yang dikonsumsi. Alasan lain diduga karena suhu dalam kandang yang sama sehinga konsumsi air minum juga sama. Coob Vantrees (2016) berpendapat bahwa konsumsi air minum lebih dari 2 kali pakan dapat terjadi pada suhu yang terlalu tinggi (di atas $30^{\circ} \mathrm{C}$ )

\section{Pengaruh Perlakuan Terhadap Pertambahan Bobot Badan Harian}

Hasil penelitian menunjukkan bahwa penambahan air perasan daun pepaya ( Carrica papaya $L)$ pada air minum ayam broiler tidak berpengaruh nyata $(\mathrm{P}>0,05)$ pada minggu 1 , 2, dan 3. Besarnya pertambahan bobot badan harian ayam broiler yang mendapat perlakuan P0, P1, P2 dan P3 tersaji pada tabel 11, 12, dan 13. 
Tabel 11. Pertambahan bobot badan harian ayam broiler dengan penambahan air perasan daun pepaya pada minggu 1 .

\begin{tabular}{ccc}
\hline Perlakuan & $\begin{array}{c}\text { Rataan } \\
\text { gram/ekor/hari }\end{array}$ & Standar Deviasi \\
\hline P0 & 34,48 & 2,91 \\
P1 & 35,25 & 1,36 \\
P2 & 35,83 & 0,74 \\
P3 & 34,38 & 2,00 \\
\hline
\end{tabular}

Tabel 12. Pertambahan bobot badan harian ayam broiler dengan penambahan air perasan daun pepaya pada minggu 2 .

\begin{tabular}{ccc}
\hline Perlakuan & $\begin{array}{c}\text { Rataan } \\
\text { gram/ekor/hari }\end{array}$ & Standar Deviasi \\
\hline P0 & 40,71 & 1,89 \\
P1 & 38,88 & 3,20 \\
P2 & 41,61 & 1,30 \\
P3 & 40,27 & 2,98 \\
\hline
\end{tabular}

Tabel 13. Pertambahan bobot badan harian ayam broiler dengan penambahan air perasan daun pepaya pada minggu 3 .

\begin{tabular}{ccc}
\hline Perlakuan & $\begin{array}{c}\text { Rataan } \\
\text { gram/ekor/hari }\end{array}$ & Standar Deviasi \\
\hline P0 & 80,79 & 1,46 \\
P1 & 78,42 & 2,77 \\
P2 & 77,01 & 3,06 \\
P3 & 76,33 & 4,85 \\
\hline
\end{tabular}

Hasil ini menunjukkan bahwa penambahan air perasan daun pepaya sampai dengan dosis $15 \mathrm{ml} /$ liter tidak berpengaruh terhadap pertambahan bobot badan harian ayam. Hal ini dipengaruhi oleh konsumsi pakan yang sama sehingga pertambahan bobot badan juga sama. Uzer et al (2013) berpendapat bahwa pertambahan bobot badan sangat berkaitan dengan pakan, dalam hal kualitas yang berkaitan dengan konsumsi pakan. Kartadisastra (1997) menambahkan bahwa pertambahan bobot badan ternak berbanding lurus dengan tingkat konsumsi pakannya. Semakin tinggi tingkat konsumsi pakannya maka akan semakin tinggi juga bobot badannya.

\section{Pengaruh Perlakuan Terhadap Konversi Pakan}

Hasil penelitian menunjukkan bahwa penambahan air perasan daun pepaya ( Carrica papaya $L)$ pada air minum ayam broiler tidak berpengaruh nyata $(\mathrm{P}>0,05)$ pada minggu 1,2 , dan 3. Besarnya konversi pakan ayam broiler yang mendapat perlakuan P0, P1, P2 dan P3 tersaji pada tabel 14, 15, dan 16.

Tabel 14. Konversi pakan ayam broiler dengan penambahan air perasan daun pepaya pada minggu 1.

\begin{tabular}{ccc}
\hline Perlakuan & $\begin{array}{c}\text { Rataan } \\
\text { gram/ekor/hari }\end{array}$ & Standar Deviasi \\
\hline P0 & 0,92 & 0,04 \\
P1 & 0,96 & 0,03 \\
P2 & 0,93 & 0,03 \\
P3 & 0,95 & 0,04 \\
\hline
\end{tabular}


Tabel 15. Konversi pakan ayam broiler dengan penambahan air perasan daun pepaya pada minggu 2.

\begin{tabular}{ccc}
\hline \hline Perlakuan & $\begin{array}{c}\text { Rataan } \\
\text { gram/ekor/hari }\end{array}$ & Standar Deviasi \\
\hline P0 & 1,33 & 0,03 \\
P1 & 1,38 & 0,05 \\
P2 & 1,36 & 0,03 \\
P3 & 1,38 & 0,07 \\
\hline
\end{tabular}

Tabel 16. Konversi pakan ayam broiler dengan penambahan air perasan daun pepaya pada minggu 3.

\begin{tabular}{ccc}
\hline Perlakuan & $\begin{array}{c}\text { Rataan } \\
\text { gram/ekor/hari }\end{array}$ & Standar Deviasi \\
\hline P0 & 1,20 & 0,02 \\
P1 & 1,22 & 0,02 \\
P2 & 1,30 & 0,06 \\
P3 & 1,24 & 0,06 \\
\hline
\end{tabular}

Hasil ini menunjukkan bahwa penambahan air perasan daun pepaya sampai dengan dosis $15 \mathrm{ml} /$ liter tidak berpengaruh terhadap konversi pakan ayam. Hal ini dipengaruhi oleh pertambahan bobot badan dan konsumsi pakan yang sama. Sesuai dengan pendapat Karyono et al (2019) bahwa pemberian ekstrak daun pepaya sampai dengan level $9 \mathrm{ml}$ dalam campuran air minum ayam arab jantan tidak memberikan pengaruh yang signifikan terhadap konversi pakan.

\section{KESIMPULAN}

Dari hasil peneltian dapat disimpulkan bahwa penambahan air perasan daun pepaya dalam air minum sampai dengan level $1,5 \%$ belum memberikan pengaruh nyata $(\mathrm{P}>0,05)$ terhadap konsumsi pakan, konsumsi air minum, pertambahan bobot badan, dan konversi pakan.

\section{DAFTAR PUSTAKA}

Aditama, F. U., B. Utomo dan N. Solikin. 2017. Pengaruh Perendaman Daging Ayam Kampung (Gallus domesticus) Bagian Paha Dalam Ekstrak Buah Nanas (Aenas comucus), Buah Mengkudu (Morinda citrifollia) dan Daun Pepaya (Carrica papaya L) Terhadap Kadar $\mathrm{pH}$, Susut Masak, dan Keempukan. Artikel Skripsi. Fakultas Peternakan Unversitas PGRI. Kediri.

Ardina, Y. 2007. Development of Antiacne Gel Formulation and Minimum Inhibitory Concentration Determination from Carrica papaya Leaves Extrat (Carrica papaya A Linn). http ://digilib.itb.ac.id/gdl.php. diakses 26 November 2020.

Citrawidi, T. A., W. Murningsih dan V. D. Y. B. Ismadi. 2012. Pengaruh Pemeraman Ransum Dengan Sari Daun Pepaya Terhadap Kolesterol Darah dan Lemak Total Ayam Broiler. Animal Agriculture Jurnal. 1 (1) : 529-540.

Cobb Vantress. 2016. Panduan Performan Broiler dan Nutrisi. www. Cobb vantress.com.

Direktorat Jenderal Peternakan dan Kesehatan Hewan Kementerian Pertanian RI. 2018. Statistik Peternakan dan Kesehatan Hewan 2018. Direktorat Jenderal Peternakan dan Kesehatan Hewan Kementerian Pertanian RI. Jakarta.

Hasil Analisis Laboratium Nutrisi Ternak Ruminansia dan Kimia Makanan Ternak Fakultas 
Peternakan Universitas Padjajaran. 2007. Fakultas Peternakan Universittas Padjajaran. Bandung.

Irianto. A. 2004. Probiotik. Gadjah Mada University Press. Yogyakarta.

Jaelani, A. 2011. Performans Ayam Pedaging Diberi Enzim Beta Mannanase Dalam Ransum Yang Berbasis Bungkil Inti Sawit. Skripsi Peternakan. Jurusan Peternakan. Fakultas Peternakan. Universitas Islam Kalimantan. Kalimantan.

Japfa Comfeed Indonesia. 2012. MB 202 (Pedaging) dan MB 402 (Petelur). PT. Japfa Comfeed Indonesia Tbk.

Kamaruddin, M. dan Salim. 2003. Pengaruh Pemberian Air Perasan Daun Pepaya Pada Ayam : Respon Patofisilogik Hepar. Jurnal Sain Veterinet 20 (1) : 37 -43

Kartadisastra, H.R. 1997. Penyediaan dan Pengolahan Pakan Ternak Ruminansia. Kanisius. Yogyakarta

Kartasudjana, R dan Suprijatna, E. 2010. Manajemen Ternak Unggas. Penebar Swadaya. Jakarta. 81-94.

Karyono, T., H. Nofrida., B. Herlina dan M. Arifin. 2019. Level Ekstrak Daun Pepaya (Carrica papaya L) Dalam Air Minum Terhadap Performans Ayam Arab Jantan Periode Starter. Jurnal Peternakan Indonesia. 21 (3) : 294-302.

Nofyangtri, S. 2007. Pengaruh Pemberian Campuran Tepung Kunyit dan Tepung Daun Pepaya Dalam Ransum Terhadap Gambaran Metabolisme Lemak Ayam Broiler Yang Mengalami Cekaman Panas. Skripsi. Program Studi Ilmu Nutrisi dan Makanan Ternak Fakultas Peternakan Institut Pertanian Bogor. Bogor.

PT. Charoen Pokphand Indonesia. 2020. Kandungan Nutrisi Pakan Merk CP 511-B. Lampung Selatan. Lampung.

Putra, T. G. 2017. Pengaruh Penambahan Tepung Daun Pepaya (Carrica papaya L) Dalam Pakan Terhadap Bobot Badan Akhir, Bobot Karkas dan Presentase Karkas Ayam Broiler. Jurnal Fapertanak. 2 (2) : 58-64.

Rasyaf, M. 2006. Beternak Ayam Pedaging. Cetakan ke 26 Penebar Swadaya. Jakarta.

Rasyaf, M. 2012. Panduan Beternak Ayam Petelur. Penebar Swadaya. Jakarta.

Siti, N. W., N. M. S. Sukmawati., I. N. Ardika., I. N. Sumerta., N. M. Witariadi., N. N. C. Kusumawati dan G. K. Roni. 2016. Pemanfaatan Ekstra Daun Pepaya Terfermentasi Untuk Meningkatkan Kualitas Daging Ayam Kampung. Majalah Ilmiah Peternakan. 19 (2) : 51 55 .

Steel, R. G. D dan J. H. Torrie. 1995. Prinsip dan Prosedur Statistika Suatu Pendekatan Biometrik. Cetakan ke 4. PT. Gramedia Pustaka Utama Jakarta. (Diterjemahkan oleh B Sumantri)

Sudjatinah, C., H.Wibowo dan P. Widyaningrum. 2005. Pengaruh Pemberian Ekstrak Daun Pepaya Terhadap Tampilan Produksi Ayam Broiler. Fakultas Tekhnologi Pertanian dan Peternakan Universitas Semarang. Semarang.

Suparman. 2017. Potensi Pengembangan Ayam Broiler di Kecamatan Malunda Kabupaten Majene. Makasar.

Suriawiria. 2002. Tanaman Berkhasiat Sebagai Obat. Papas Sinar Sinanti. Jakarta

Swennen, Q., Delezie, E., Collin, A.,Decuypere, E., Buyse, J. 2007. Further Investigations On The Role of Diet-Induced Thermogenesis In The Regulation of Feed Intake In Chickens. Comparison of Age-Matched Broiler Versus Layer Cockerels. Poultry Sci 86 (5): 895-903.

Uzer, F., N. Irianti dan Rosediyanto. 2013. Penggunaan Pakan Fungsional Dalam Ransum Terhadap Konsumsi Pakan dan Pertambahan Bobot Badan Ayam Broiler. J. Ilmiah 
Peternakan. 1 (1): 282-288.

Wahju, J. 2004. Ilmu Nutrisi Unggas. Gajah Mada University Prees. Yogyakarta..

Wijayanti, R. W., W,. Busono., dan I. Rositawari. 2011. Pengaruh Suhu Kandang Terhadap Performans Ayam Pedaging Periode Starter. 